\title{
WAMCA - exclusieve belangenbehartiger, inclusief complicaties
}

\author{
Branda Katan en Marnix Wallinga*
}

\section{Inleiding}

De Wet afwikkeling massaschade in collectieve actie (WAMCA ${ }^{1}$ ) heeft nieuwe fenomenen in het burgerlijk procesrecht geïntroduceerd, waaronder die van de exclusieve belangenbehartiger (hierna: EB). De wet trechtert vorderingen van verschillende eiseressen ${ }^{2}$ tegen dezelfde gedaagde tot één procedure. De EB treedt in de samengevoegde procedure op voor de belangen van alle personen voor wie de collectieve actie is ingesteld. Dit model beoogt te voorkomen dat angesproken partijen worden geconfronteerd met collectieve acties door verschillende belangenbehartigers die opkomen voor de belangen van (deels) dezelfde gedupeerden. ${ }^{3}$ Het basismodel gaat uit van één EB en een ondergeschikte rol voor de andere eiseressen.

In de praktijk kunnen zich conflictsituaties en complicaties voordoen bij concurrerende belangenbehartigers waarvoor wet en wetsgeschiedenis geen oplossing bieden. Veel is namelijk niet uitdrukkelijk geregeld, soms wijken partijen af van de regels en soms is onduidelijk hoe de belangen van alle (potentiele) procespartijen gewaarborgd worden. In deze bijdrage verkennen wij een aantal scenario's en knelpunten die op de loer liggen in verschillende fases van een collectieve procedure. Achtereenvolgens komen aan bod:

- Aanvang van de procedure: uitbrengen, indienen en publiceren van de dagvaarding (par. 2);

- Concurrerende belangenbehartigers en de aanloop naar benoeming van de EB: 'verkeerd' uitgebrachte dagvaardingen, verlenging van de termijn en andere verwikkelingen (par. 3);

\footnotetext{
Mr. dr. B.M. Katan is advocaat bij Stibbe te Amsterdam en fellow aan de Radboud Universiteit Nijmegen. Mr. dr. M.W. Wallinga is advocaat bij Stibbe te Amsterdam en verbonden aan het Groningen Centre for European Financial Services Law.

1. Art. 3:305a-305d BW en art. $1018 \mathrm{~b}-1018 \mathrm{~m} \mathrm{Rv}$.

2. Aangezien een collectieve belangenbehartiger een stichting of vereniging moet zijn, zal altijd sprake zijn van een eiseres. Om diezelfde reden refereren wij in dit artikel aan een belangenbehartiger met 'zij'.

3. Bijv. dat de overlappende leden van de achterban van belangenorganisaties gebonden worden aan uiteenlopende en mogelijk onderling tegenstrijdige vonnissen of dat deze leden de opt-outtermijn van de ene procedure kunnen negeren om gebruik te maken van de termijn in een andere procedure.
}

- Aanwijzing van de EB: proces, criteria en modaliteiten (par. 4);

- (Dis)functioneren van de EB bij het voeren van de collectieve procedure: conflictsituaties en dergelijke (par. 5).

Deze bijdrage betreft mede een verkenning van scenario's die zich naar ons weten nog niet hebben voorgedaan en waarin zich omstandigheden kunnen voordoen die wij op voorhand niet kunnen voorzien. Het heeft hier en daar dus een wat speculatief en inventariserend karakter. Wij veronderstellen de lezer vertrouwd met het basale systeem van de WAMCA.

$\mathrm{W}_{\mathrm{ij}}$ laten procedures in kort geding buiten beschouwing, nu daarin geen EB wordt aangewezen (art. 1018b lid 1 Rv). Wij laten eveneens procedures buiten beschouwing die om ideële redenen worden gevoerd en waarin de eiseres een beroep doet op art. 3:305a lid $6 \mathrm{BW}$. Dit is omdat wij ervan uitgaan dat er bij ideële acties eerder samenwerking dan concurrentie zal bestaan tussen de betrokken belangenbehartigers. Daarnaast beperken wij ons met het oog op de omvang van deze bijdrage tot procedures in eerste aanleg. Dat betekent dat wij interessante vragen zoals wie beslist over het instellen van hoger beroep in een collectieve procedure, niet behandelen.

'Concurrerende vorderingen' zijn tot op heden overigens slechts ingesteld in 1 van de 29 WAMCA-zaken die tot en met juni 2021 aanhangig zijn gemaakt. ${ }^{4}$ Dit betreft de zaak over dieseluitstoot van Mercedes-Benz-voertuigen in verband met vermeende 'sjoemelsoftware' waarmee deze voertuigen zouden zijn uitgerust. ${ }^{5}$

\section{Aanhangig maken van een WAMCA-procedure}

\subsection{Inleiding: van KEI naar traditioneel}

Van belang voor een goed begrip van de bepalingen in de WAMCA die de aanvang van de procedure betreffen, is dat het wetsvoorstel oorspronkelijk is geschreven voor procedures

4. Bij het getal 29 zijn de twee zaken tegen Yisp/Worldstream als één zaak geteld.

5. De auteurs van deze bijdrage staan enkele gedaagden in die procedure bij als advocaat. Om die reden zullen wij ons niet uitlaten over onderwerpen die in deze procedure aan bod (kunnen) komen. 
die zouden worden gevoerd op grond van het KEI-procesrecht. In grote lijnen was de beginfase van een KEI-procedure in vorderingszaken als volgt voorzien (wij laten uitzonderingen en details buiten beschouwing): ${ }^{6}$

- De eiser dient een procesinleiding in bij de rechtbank, met daarin een zelf bepaalde termijn waarbinnen de verweerder moet verschijnen (minimaal vier weken, maximaal zes maanden; art. 30a lid 3 sub c KEI-Rv);

- De zaak is aanhangig vanaf de indiening van de procesinleiding (art. 125 KEI-Rv);

- De griffie maakt een oproepingsbericht aan en stuurt dat naar de eiser (art. 111 lid 1 KEI-Rv);

- De eiser laat het oproepingsbericht binnen twee weken na indiening van de procesinleiding bezorgen of betekenen aan de verweerder (art. $112 \mathrm{KEI}-\mathrm{Rv}$ );

- Het staat de verweerder vrij om op een willekeurig vroeger moment dan de uiterste datum te verschijnen; vaste roldata zouden worden afgeschaft (art. 30a lid 3 sub c KEI-Rv).

Terwijl het WAMCA-wetsvoorstel in behandeling was bij de Tweede Kamer, werd steeds duidelijker dat KEI niet landelijk zou worden ingevoerd, althans niet voordat de WAMCA van kracht zou worden. Op 29 januari 2019 diende de minister een gewijzigd voorstel in met daarin titel IIa. Titel IIa bevatte dezelfde wetsartikelen als titel II, maar dan aangepast aan de traditionele procedure. Omdat de behandeling in de Kamer al vergevorderd was - het regende in diezelfde periode amendementen -, is de aangepaste versie vermoedelijk met enige haast opgesteld. De diverse plooien die de rechtbank Amsterdam daardoor heeft moeten gladstrijken, zijn in eerdere publicaties al aan de orde gekomen. ${ }^{7}$

\subsection{Eerst: dagvaarding uitbrengen}

Een WAMCA-procedure wordt net als andere vorderingszaken aanhangig gemaakt met het uitbrengen van een dagvaarding (art. 125 lid $1 \mathrm{Rv}$ ). In niet-collectieve procedures moet de dagvaarding uiterlijk een dag voor de aangezegde roldatum ter griffie zijn ingediend (art. 125 lid $2 \mathrm{Rv}$ ). In de tussentijd gebeurt er doorgaans niets waar de gedaagde van op de hoogte moet zijn. Bij een collectieve actie kan echter van alles gebeuren achter de schermen tussen de datum van dagvaarding en de eerstdienende dag. Zoals wij hierna toelichten, bevat de WAMCA geen waarborgen dat alle betrokkenen hiervan tijdig op de hoogte worden gesteld.

\subsection{Snel! Indienen bij griffie en centraal register}

Het exploot van de uitgebrachte dagvaarding moet binnen twee dagen na de dag van dagvaarding worden ingediend ter griffie. Een afschrift van de dagvaarding moet gelijktijdig ter

6. Zie H. van Dam-Lely, 'KEI vereenvoudigt de civiele procedure (of niet?)', $A A 2017$, afl. 5, p. 374-380 en T.F.E. Tjong Tjin Tai, 'Termijnen voor oproeping en verschijnen onder KEI', TCR 2016, afl. 3, p. 63-70.

7. B.M. Katan, 'De WAMCA op je bord', NTBR 2020/37; noot Wijnberg en Hoogervorst onder Rb. Amsterdam 1 april 2020, ECLI:NL:RBAMS: 2020:2842, JBPr 2021/2. publicatie worden toegezonden aan het centraal register (art. 1018c lid $2 \mathrm{Rv}$ ).

De tijdige aantekening in het centraal register heeft een duidelijk doel: vanaf dat moment gaat de termijn van drie maanden lopen waarin andere belangenbehartigers een concurrerende vordering aanhangig kunnen maken (art. 1018d lid $1 \mathrm{Rv}$ ). De wet stelt niet de eis dat het exploot van de dagvaarding in het register wordt aangetekend, maar 'een afschrift van de dagvaarding'. In de praktijk stuurt de eiseres aan het centraal register een pdf van de dagvaarding zoals die aan de deurwaarder is gestuurd, zonder deurwaardersstempels, en - als het goed is - geanonimiseerd volgens de regels van het Besluit register collectieve vorderingen. ${ }^{8}$

De verplichting tot publicatie van een processtuk is, voor zover wij kunnen overzien, een novum in het burgerlijk procesrecht. In Nederland zijn buiten de WAMCA uitsluitend gerechtelijke uitspraken openbaar of op te vragen. Dat geschillen tussen private partijen in dit digitale tijdperk niet zomaar 'open en bloot' op straat liggen, achten wij een groot goed.

In dat kader hebben wij twijfels bij de verplichting om de gehele dagvaarding in het centraal register te publiceren. Voor het informeren van concurrerende belangenbehartigers volstaat een uittreksel met een samenvatting van de feiten en rechtsgronden en een weergave van het petitum. Eerder schreef een van ons al dat de omzetting van 'uittreksel van de procesinleiding' (KEI) naar 'afschrift van de dagvaarding' ongelukkig is geweest. Concurrerende belangenbehartigers kunnen nu gratis profiteren van het feitenonderzoek en het juridische voorwerk (en daarmee van de investeringen) van de oorspronkelijke belangenbehartiger. ${ }^{9}$ Zie daarover meer in paragraaf 4.1 .

Ook de belangen van gedaagden worden door publicatie van de dagvaarding geraakt, omdat voor de hele wereld (blijvend) vindbaar wordt dat de gedaagde in een procedure is betrokken en wat hem of haar wordt verweten, nog voordat een rechterlijke toets heeft plaatsgevonden. Zeker bij natuurlijke personen kan dit zeer ingrijpend zijn. Diverse rechtbanken hebben daarom besloten om, in weerwil van de toelichting op het Besluit register collectieve vorderingen, niet de naam van de gedaagde in het register op te nemen indien de gedaagde een natuurlijke persoon is. ${ }^{10}$ De naam van de gedaagde kan uitsluitend door een advocaat schriftelijk bij de rechtbank worden opgevraagd. ${ }^{11}$ Hoewel dit betekent dat een belangen-

8. Volgens de toelichting op dit Besluit mogen de namen van partijen niet worden geanonimiseerd. Dit voorschrift wordt door diverse belangenbehartigers niet opgemerkt. In de dagvaarding die op 8 april 2021 in het centraal register is ingeschreven onder de naam SFiM/Staat der Nederlanden wordt zelfs de collectieve belangenbehartiger slechts aangeduid als 'eiser'.

9. B.M. Katan, 'De WAMCA op je bord', NTBR 2020/37.

10. Besluit van 20 november 2019 , houdende aanwijzing van de Raad voor de rechtspraak als houder van het centraal register voor collectieve vorderingen, Stb. 2019/446.

11. Zie centraal register, dagvaardingen van 23 juli 2020, 4 januari 2021, 24 februari 2021 en 29 maart 2021, telkens ingesteld door Stichting BREIN. 
behartiger die een collectieve actie voorbereidt, grondiger moet gaan bijhouden of een concurrent mogelijk al een actie is begonnen, vinden wij dit een aanvaardbaar compromis. Dergelijke belangenbehartigers moeten toch al op regelmatige basis het register raadplegen, want een 'alert-functie' heeft het centraal register vooralsnog niet.

Het doel van de snelle indiening van het exploot ter griffie is minder duidelijk dan dat van de publicatie in het centraal register. Vanuit KEI-perspectief was de indiening ter griffie het startpunt van de procedure zelf. Het is logisch dat het moment waarop de zaak aanhangig wordt, zo veel mogelijk samenvalt met het startmoment voor de termijn om een concurrerende collectieve actie aanhangig te maken (art. 1018d lid $1 \mathrm{Rv}$ ). Gezien de twee weken die een eiser onder KEI kreeg om het oproepingsbericht aan de gedaagde te versturen, kon het onder KEI zelfs voorkomen dat de procesinleiding in het centraal register te lezen was nog voordat gedaagde deze ontvangen had.

Bij traditioneel procederen is de zaak aanhangig vanaf de betekening van de dagvaarding en is de gedaagde dus direct op de hoogte. Indiening ter griffie op een eerder moment dan een dag voor de aangezegde roldatum heeft dan niet echt een doel. Hooguit stelt het de rechtbank in staat te controleren of een andere collectieve actie (of een verzoek om termijnverlenging voor het aanhangig maken daarvan) concurreert met een daadwerkelijk bestaande procedure - en niet met een fantoomprocedure die alleen in het centraal register bestaat. Een dergelijke controle is vanzelfsprekend alleen nodig indien het bericht van de concurrerende belangenbehartiger de rechtbank bereikt vóór de eerstdienende dag. Om voor zo'n situatie een afwijkende regel over indiening van de dagvaarding ter griffie in de wet op te nemen, zelfs op straffe van niet-ontvankelijkheid, is wel erg ingrijpend. ${ }^{12}$

Dat de wet geen voorziening voor herstel biedt, is in dat licht eveneens ongelukkig. ${ }^{13}$ In de Stop Online Shaming-zaak, waarin het exploot een dag voor de aangezegde roldatum was ingediend, besloot de rechtbank de sanctie van niet-ontvankelijkheid geheel terzijde te schuiven:

'Aldus is de te late indiening ter griffie in dit geval niet meer dan een administratief verzuim waardoor geen (potentiële) procespartijen in hun belangen zijn geschaad, een administratief verzuim dat ook voor het overige geen blijvende nadelige gevolgen heeft gehad of zal hebben. ${ }^{14}$

Wat is nu de situatie indien de dagvaarding wel is uitgebracht en een kopie in het centraal register is gepubliceerd, maar de

12. Als alternatief had men bijv. kunnen denken aan een plicht voor de eiseres om de rechtbank het exploot op eerste verzoek binnen een door de rechtbank gestelde termijn te verschaffen.

13. Het vereiste dat het exploot van dagvaarding in het centraal register moet worden aangetekend, stelt de eiseres overigens ook voor een praktisch probleem. $\mathrm{Zij}$ zal het exploot lang niet altijd binnen een dag terugontvangen van de deurwaarder.

14. Rb. Amsterdam 1 april 2020, ECLI:NL:RBAMS:2020:2842, r.o. 3.6. griffie geen exploot heeft ontvangen? Als op een lange termijn is gedagvaard, kan het gebeuren dat de rechtbank voor de eerstdienende dag moet beslissen over het verlengen van de termijn voor het uitbrengen van een concurrerende dagvaarding, of tot voeging in de zin van art. 1018c lid 6 Rv. De wet lijkt te zeggen dat de rechtbank de eiseres 'aanstonds' niet-ontvankelijk moet verklaren, omdat het exploot niet tijdig bij de griffie is ingediend (art. 1018c lid $3 \mathrm{Rv}$ ). Die niet-ontvankelijkheid kan, aldus de rechtbank Amsterdam, worden uitgesproken nog vóór de roldatum waartegen is gedagvaard en zonder de gedaagde te horen. ${ }^{15}$

Hoe kan de rechtbank zich niet-ontvankelijk verklaren als zij niet kan vaststellen dat de procedure überhaupt aanhangig is? Zij zou het exploot bij de eiseres kunnen opvragen - waarom niet? Maar als de rechtbank het exploot van de overigens correct uitgebrachte dagvaarding eenmaal heeft ontvangen, welk rechtens te respecteren belang bestaat er dan nog bij nietontvankelijkheid? Het alternatief is dat de rechtbank direct - maar ten onrechte - constateert dat er geen procedure aanhangig is. Dan zit er voor de eiseres weinig anders op dan een nieuwe dagvaarding te laten betekenen. Indien dit alles zich afspeelt voor de eerstdienende dag, zal de rechtbank naar onze mening overigens wel de - in de ogen van de rechtbank: mogelijke - gedaagde op de hoogte moeten brengen van haar vermoeden dat geen procedure aanhangig is. De rechtbank zal er altijd rekening mee moeten houden dat de dagvaarding wel correct is betekend en dat de gedaagde dus in de veronderstelling leeft dat zij zich tegen de betekende dagvaarding zal moeten gaan verweren.

In dat verband rijst de vraag hoe de rechtbank met de gedaagde kan communiceren over perikelen die zich voordoen vóór de eerstdienende dag. Partijen mogen alleen verschijnen bij advocaat, maar er zal zich in die periode nog niemand hebben gesteld. De rechtbank zou de gedaagde kunnen aanschrijven op het adres dat in de dagvaarding is genoemd, en meedelen dat de reactie door een advocaat moet worden ingediend. Bij grote ondernemingen kan dit gemakkelijk mislopen: een brief die wordt gestuurd aan het statutaire adres, zonder vermelding van een persoon of afdeling - en mogelijk in een taal die men bij de postkamer niet beheerst, kan gemakkelijk weken rondzwerven binnen een organisatie. Om dit te voorkomen zou de griffie contactgegevens uit het vooraf gevoerde overleg (art. 3:305a lid 3 sub c BW) bij de eiseres kunnen opvragen, maar dit biedt geen garantie, want belangenbehartigers krijgen niet altijd een reactie op hun brieven. Gedaagden die willen voorkomen dat zij verstoken blijven van informatie, kunnen het beste zelf vroegtijdig advocaat stellen.

De eiseres die meent dat zij ten onrechte op deze grond nietontvankelijk is verklaard, hoeft niet in hoger beroep. $\mathrm{Zij}$ kan

15. Rb. Amsterdam 1 april 2020, ECLI:NL:RBAMS:2020:2842, r.o. 3.5 
gewoon opnieuw een dagvaarding uitbrengen, nu de rechtbank in deze situatie geen inhoudelijk oordeel heeft geveld. ${ }^{16}$

\section{De aanloop naar de benoeming van een EB: wie mag meedoen?}

\subsection{Verkeerd uitgebrachte concurrente vordering en hoor en wederhoor}

Een concurrerende belangenbehartiger moet de gedaagde dagvaarden binnen drie maanden na de aantekening van de oorspronkelijke vordering in het centraal register, voor dezelfde rechtbank als de oorspronkelijke eiseres (tenzij uitstel wordt verleend, waarover par. 3.2). Indien de concurrerende belangenbehartiger te laat is of niet in concurrentie wil treden, kan zij proberen de gebeurtenissen zo te omschrijven of de rechtsgronden voor de vordering zo te kiezen dat verdedigbaar is dat het niet dezelfde gebeurtenissen betreft en dat de feitelijke en rechtsvragen onvoldoende gelijksoortig zijn aan die in de reeds aanhangige procedure. De collectieve vordering valt dan niet onder de regels van art. $1018 \mathrm{~d}$ Rv. Er valt niet veel te zeggen over hoe de rechtbank dit betoog moet beoordelen; het zal afhangen van de onderliggende feiten en de wijze waarop beide collectieve vorderingen zijn ingestoken. Mogelijk zal ook een rol spelen of de tweede belangenbehartiger dezelfde groep gedaagden kiest.

Indien de rechtbank van oordeel is dat de concurrerende dagvaarding wel op dezelfde feiten en belangen ziet én te laat is uitgebracht, ligt het voor de hand dat de rechtbank de tweede eiseres niet-ontvankelijk zal verklaren. De rechtbank is dan immers op processuele gronden niet toegekomen aan een inhoudelijke beoordeling van de vordering. ${ }^{17}$

Titel $14 \mathrm{a} \mathrm{Rv}$ schrijft niet voor of de rechtbank de gedaagde en de oorspronkelijke belangenbehartiger in de gelegenheid moet stellen zich uit te laten over de ontvankelijkheid van de tweede belangenbehartiger in dit kader. Wij zouden menen dat een verplichting hiertoe volgt uit het beginsel van hoor en wederhoor (art. $19 \mathrm{Rv)}$ ). De regel dat de rechtbank een eiseres 'aanstonds' niet-ontvankelijk kan verklaren, geldt alleen voor het geval de oorspronkelijke dagvaarding niet tijdig is aangetekend in het centraal register of ingediend bij de griffie.

Dat de gedaagde gehoord moet worden, ligt voor de hand. De oorspronkelijke eiseres is echter geen partij bij de procedure die door de tweede eiseres is opgestart - althans, niet zolang niet vaststaat dat de tweede collectieve vordering overeenkom-

16. Vgl. E. Gras, R.G. Hendrikse \& A.W. Jongbloed, Stein/Rueb. Compen dium van het burgerlijk procesrecht, Deventer: Wolters Kluwer 2021, par. 9.3.2.

17. Jongbloed, in: GS Vermogensrecht, art. 3:303 BW, aant. 2. De conceptMvT bij Implementatiewet richtlijn representatieve vorderingen voor consumenten gaat ervan uit dat in een dergelijk geval wordt geoordeeld dat de concurrerende belangenbehartiger onvoldoende belang heeft bij zijn vordering in de zin van art. 3:303 BW (p. 17). stig art. $1018 \mathrm{~d} \mathrm{Rv}$ is ingesteld. ${ }^{18}$ Zodra dat echter wel zou komen vast te staan - en dat is precies wat de rechtbank moet beoordelen -, wordt de oorspronkelijke eiseres wél partij. De beslissing van de rechtbank beinvloedt bovendien het verloop van de oorspronkelijke procedure. Al met al voldoende rechtvaardiging om een verplichting van de rechtbank aan te nemen om de oorspronkelijke eiseres te horen. Strikt genomen zou de oorspronkelijke eiseres naar onze mening ook in de procedure tussen de concurrerende belangenbehartiger en de gedaagde moeten kunnen tussenkomen of zich daarin moeten kunnen voegen, of op de voet van art. $118 \mathrm{Rv}$ in het geding moeten worden geroepen. De oorspronkelijke eiseres heeft immers een eigen belang bij de uitkomst (zie ook de bespiegelingen hierna over de situatie in hoger beroep). De vertraging en formaliteiten die daarmee gemoeid zijn, kunnen worden voorkomen door de oorspronkelijke eiseres eenvoudigweg in de gelegenheid te stellen zich uit te laten over de tijdigheid en gelijksoortigheid van de tweede collectieve vordering; wij zien geen bezwaar tegen zo'n praktische aanpak. Een alternatief kan zijn om art. $1018 \mathrm{~d}$ lid $3 \mathrm{Rv}$ ruim te interpreteren, alsof de rechtbank de diverse collectieve vorderingen als één zaak moet behandelen vanaf het moment dat zij een dagvaarding of verlengingsverzoek van de concurrerende belangenbehartiger heeft ontvangen, in plaats van na inschrijving op de rol. Dat is echter wel een vérgaande stap bij een wet die nog maar zo kort geleden door het parlement is aangenomen.

De oorspronkelijke eiseres en gedaagde hoeven wat ons betreft overigens niet te worden gehoord indien de tweede dagvaarding evident ('kennelijk') niet-ontvankelijk is, bijvoorbeeld omdat deze evident over dezelfde feiten en belangen gaat, ruim te laat is uitgebracht en geen argumentatie bevat over de tijdigheid of over de verschillen met de oorspronkelijke dagvaarding.

Indien de tweede eiseres niet-ontvankelijk wordt verklaard omdat de tweede collectieve vordering op dezelfde feiten en belangen ziet én te laat is uitgebracht, staat tegen dit vonnis naar onze mening hoger beroep open. De concurrerende belangenbehartiger wordt immers materieel in haar positie geraakt, en het opnieuw uitbrengen van een dagvaarding is zinloos.

Wie zijn partij bij de procedure in hoger beroep tegen de nietontvankelijkverklaring van de concurrerende belangenbehartiger? De oorspronkelijke gedaagde zal in ieder geval partij zijn. De oorspronkelijke eiseres is dat nog steeds niet. De oorspronkelijke eiseres kan wel belang hebben bij de uitkomst van het hoger beroep: zij zal willen voorkomen dat de tweede eiseres alsnog ontvankelijk wordt verklaard en dat de tweede vordering aangemerkt wordt als gelijksoortige collectieve

18. Zie art. $1018 \mathrm{~d}$ lid $3 \mathrm{Rv}$, dat overigens verkeerd is geredigeerd. Naar de letter bepaalt art. $1018 \mathrm{~d}$ lid $3 \mathrm{Rv}$ uitsluitend dat de tweede en volgende collectieve vorderingen als één zaak moeten worden behandeld, niet tevens de overeenkomstig art. $1018 \mathrm{c} \mathrm{Rv}$ oorspronkelijk ingestelde collectieve vordering. De rechtbank Amsterdam heeft dit opgemerkt in een niet-gepubliceerde rolbeslissing in de dieselzaak tegen Daimler c.s. 
vordering in de zin van art. 1018d lid $1 \mathrm{Rv}$. Indien de oorspronkelijke gedaagde in hoger beroep pleit voor handhaving van het vonnis in eerste aanleg, kan de oorspronkelijke eiseres zich voegen aan de zijde van de gedaagde. Indien deze niet hetzelfde standpunt bepleit als de oorspronkelijke eiseres of niet verschijnt, zal de oorspronkelijke eiseres moeten tussenkomen.

De rechtbank doet er intussen verstandig aan om de behandeling van de collectieve vordering van de oorspronkelijke eiseres aan te houden. Indien in de procedure in hoger beroep tussen de concurrerende belangenbehartiger en de gedaagde wordt geoordeeld dat de concurrerende belangenbehartiger wél op tijd was, zal zij immers als partij in de oorspronkelijke procedure gaan gelden en mogen meedingen naar de positie van EB. Datzelfde geldt overigens indien een van de concurrerende eiseressen in hoger beroep gaat omdat zij nietontvankelijk is verklaard wegens het niet-voldoen aan de vereisten van art. 3:305a BW.

Wat gebeurt er als een onbetwistbaar concurrerende collectieve vordering tijdig wordt aangebracht, maar bij een andere rechtbank? Indien dit gebeurt voordat de oorspronkelijke dagvaarding is aangetekend in het register, dient de 'tweede rechtbank' de zaak te verwijzen naar de rechtbank van de eerst aanhangig gemaakte collectieve vordering, zo bepaalt art. $1018 \mathrm{c}$ lid $6 \mathrm{Rv}$. Aangezien deze regeling uitsluitend is opgenomen voor het geval de eerste collectieve vordering nog niet gepubliceerd was, nemen wij aan dat de tweede rechtbank de concurrerende belangenbehartiger niet-ontvankelijk moet verklaren indien zij na die tijd de gedaagde dagvaardt voor de tweede rechtbank. Art. 110 lid 2 Rv (verwijzing indien gedagvaard voor relatief onbevoegde rechtbank) is echter niet uitdrukkelijk uitgesloten.

Indien de tweede rechtbank de concurrerende belangenbehartiger niet-ontvankelijk verklaart voordat de drie maanden verstreken zijn, kan de concurrerende belangenbehartiger de gedaagde alsnog dagvaarden voor de eerste rechtbank. In de parlementaire geschiedenis van de WAMCA merkt de minister overigens op dat de concurrerende belangenbehartiger ' $m e t$ een gerust hart' de gedaagde mag dagvaarden voor de oorspronkelijke rechtbank, ook indien zij meent dat die relatief onbevoegd is. ${ }^{19}$

\subsection{Verzoek tot verlenging}

De concurrerende belangenbehartiger die voorziet dat het haar niet gaat lukken om binnen de termijn van drie maanden een concurrerende dagvaarding uit te brengen, kan binnen een maand na de aantekening van de oorspronkelijke dagvaarding in het centraal register de rechtbank verzoeken om verlenging. De rechtbank kan de termijn met maximaal drie maanden verlengen (art. 1018d lid $2 \mathrm{Rv}$ ).

De wet geeft geen criteria waaraan de rechtbank het verlengingsverzoek moet toetsen. De memorie van toelichting geeft als voorbeeld van redenen tot verlenging 'de aard van de

19. Kamerstukken II 2016/17, 34608, nr. 7, p. 6 (NvW). collectieve vordering' of dat organisaties vanwege het samenwerkingsverband dat zij willen aangaan om een gezamenlijke collectieve vordering in te dienen, meer dan drie maanden nodig hebben om de vordering voldoende voor te bereiden. ${ }^{20}$ In de dieselzaak tegen Daimler c.s. werd aan een concurrerende belangenbehartiger uitstel verleend omdat de materie complex werd geacht en de concurrerende belangenbehartiger binnen de verlengingstermijn relevante uitspraken verwachtte van het Hof van Justitie van de Europese Unie en het Bundesgerichtshof. Het uitstel werd beperkt tot twee maanden, omdat de concurrerende belangenbehartiger al ruim een maand op de hoogte was van de oorspronkelijke dagvaarding op het moment dat die in het centraal register was aangetekend. ${ }^{21}$

Daarbij is het overigens de vraag of een tweede concurrerende belangenbehartiger die niet zelf een verzoek tot uitstel heeft ingediend (art. 1018d lid $2 \mathrm{Rv}$ ), mag meeliften op het uitstel dat aan de eerste concurrent is verleend. Indien de tweede concurrent dat in beginsel zou mogen, moet zij dan al opgericht zijn ten tijde van het uitstelverzoek van de eerste concurrent? Wij laten ons niet uit over het antwoord op deze vragen, aangezien zij spelen in de dieselzaak tegen Daimler c.s. waarin wij, zoals vermeld, enkele gedaagden bijstaan als advocaat.

Bij het verlengingsverzoek geldt wat ons betreft hetzelfde als bij de niet tijdig uitgebrachte concurrerende dagvaarding: de oorspronkelijke eiseres is bij de concurrerende procedure (nog) geen partij, maar wel belanghebbende. Het beginsel van hoor en wederhoor brengt mee dat zij gehoord moet worden over het verzoek. In dit geval is gedaagde ook nog geen partij, aangezien de concurrerende dagvaarding nog niet is uitgebracht. De gedaagde kan echter ook als belanghebbende worden beschouwd, ook al betreft het geen verzoekschriftprocedure in de zin van art. 261 e.v. Rv. Beide partijen kunnen de rechtbank nuttige informatie verschaffen over de juistheid van de informatie in het verlengingsverzoek en over andere omstandigheden die van belang kunnen zijn voor de beslissing.

Curieus genoeg werd in de dieselzaak tegen Daimler c.s. de beslissing op het verzoek tot verlenging van de concurrerende belangenbehartiger gegoten in de vorm van een rolbeslissing in de oorspronkelijke procedure. De concurrerende belangenbehartiger die het verzoek tot verlenging had gedaan, werd daarin niet als partij genoemd. De aanhouding van de oorspronkelijke procedure in verband met de termijnverlenging is vanzelfsprekend een rolbeslissing in de oorspronkelijke procedure, maar de toekenning van de termijnverlenging is dat naar ons idee niet.

20. Kamerstukken II 2016/17, 34608, nr. 3, p. 41 (MvT).

21. Rb. Amsterdam 30 september 2020, gepubliceerd in centraal register. 


\section{Aanwijzing van de EB: proces en criteria}

\subsection{Het proces: een gelijk speelveld?}

Uit de belangenbehartigers die op correcte wijze en binnen de (verlengde) termijn een collectieve actie hebben ingesteld, wijst de rechter een EB aan. De volgorde waarin de collectieve vorderingen aanhangig worden gemaakt, heeft geen invloed op aanwijzing van de EB. Anders gezegd: de eerste en concurrerende belangenbehartiger(s) maken in principe gelijke kans om te worden aangewezen als EB. Dit kan voorkomen dat na een schadeveroorzakende gebeurtenis een 'rush to court' plaatsvindt die vanuit kwaliteitsoogpunt onwenselijk is. ${ }^{22}$

In de praktijk kan het gebeuren dat de eerste belangenbehartiger die een collectieve vordering instelt, weinig aandacht besteedt aan waarom zij moet worden aangewezen als EB. Deze belangenbehartiger zal zich in sommige gevallen niet bewust zijn van mogelijke kapers op de kust. Een concurrerende belangenbehartiger heeft dan een - naar wij aannemen door de wetgever onvoorzien - voordeel. Niet alleen weet de concurrerende belangenbehartiger met welke partij zij moet wedijveren om de positie van EB. Zij kan zich ook gericht afzetten tegen de eerste eiseres en haar feitelijke en juridische positie en stellingen ondergraven in een poging om zelf aangewezen te worden als EB. De concurrerende belangenbehartiger beschikt immers over het afschrift van de dagvaarding in het centraal register. Mede gelet op het beginsel van hoor en wederhoor ligt het voor de hand dat de rechter de eerste eiseres de gelegenheid geeft om zich (nader) uit te laten over wie moet worden aangewezen als EB, of in ieder geval over de stellingen van de concurrerende belangenbehartigers daaromtrent. $^{23}$

\subsection{Selectiecriteria}

De wet noemt een aantal selectiecriteria die de rechter kan gebruiken bij aanwijzing van de meest geschikte eiseres als EB:

1. De omvang van de groep personen wiens belangen worden behartigd;

2. De grootte van het door deze groep vertegenwoordigde financiële belang;

3. Andere werkzaamheden die eiseres verricht voor personen voor wie zij opkomt in of buiten rechte; en

4. Eerdere werkzaamheden die eiseres heeft verricht of collectieve vorderingen die zij heeft ingesteld (art. 1018e lid $1 \mathrm{Rv})$.

De rechtbank is vrij in het bepalen van de waarde die zij in een concreet geval toekent aan elk van deze criteria bij het aanwijzen van de EB. ${ }^{24}$ Wel dient zij haar keuze te motiveren. ${ }^{25}$

22. Kamerstukken II 2016/17, 34608, nr. 3, p. 35 (MvT).

23. Zo heeft de rechtbank Amsterdam in de collectieve vordering tegen Daimler c.s. belangenbehartigers de gelegenheid gegeven om zich uit te laten over elkaars positie over o.a. aanwijzing van een EB: rolbeslissing 21 april 2021 (te raadplegen via het centraal register voor collectieve vorderingen), r.o. 2.13

24. Kamerstukken II 2016/17, 34608, nr. 3, p. 43 (MvT).

25. Kamerstukken II 2016/17, 34608, nr. 3, p. 43 (MvT).
De rechtbank komt pas toe aan aanwijzing van de EB als zij de ontvankelijkheid van de daarvoor in aanmerking komende belangenbehartigers heeft vastgesteld (art. 3:305a BW). Daarbij valt op dat de selectiecriteria overeenkomsten vertonen met de onder de WAMCA aangescherpte ontvankelijkheidseisen voor wat betreft representativiteit en geschiktheid om een collectieve procedure te voeren. ${ }^{26}$ Dat is ook niet zo gek: de organisatie die als EB wordt aangewezen om de belangen van alle personen in de collectieve procedure te behartigen, moet daartoe ook in staat zijn. Anders gezegd: de vraag of een belangenbehartiger in staat is om een collectieve procedure te voeren, loopt logischerwijs over in de vraag of deze belangenbehartiger daarvoor geschikter is dan een concurrent.

Dat roept de vraag op of het systeem van de wet op grond waarvan eerst voor elke belangenbehartiger de ontvankelijkheid wordt vastgesteld en daarna een EB wordt aangewezen, wel zo voor de hand ligt. In sommige gevallen zal het logischer zijn om beoordeling van de ontvankelijkheid en aanwijzing van de EB samen te voegen. De rechter heeft ook de vrijheid om de collectieve procedure op de gewenste manier in te richten - en heeft die genomen in de dieselzaken. ${ }^{27}$ De verwachting is in ieder geval dat de rechter bij zijn beoordeling van welke eiseres het meest geschikt is als EB, ook acht slaat op de gegevens die eiseressen aanleveren om aan te tonen dat zij voldoen aan de ontvankelijkheidseisen.

Een belangenbehartiger die in aanmerking wil komen voor de positie van EB zal zo veel mogelijk personen aan zich willen binden, met het in totaal grootst mogelijke financiële belang. ${ }^{28}$ Om dat te bereiken valt te verwachten dat belangenbehartigers in een zo vroeg mogelijk stadium in het kader van de 'beauty contest' inzetten op het gebruik van sociale media, zoals Facebook, Twitter en Instagram. Denkbaar is ook dat belangenbehartigers grote partijen benaderen om zich aan te sluiten bij hun collectieve vordering, zoals institutionele beleggers bij beleggingsschade of gedupeerde winkelketens en verkoopplatforms bij productiefouten in consumptiegoederen.

Hierbij dient men erop bedacht te zijn dat de grootte van de achterban en het vertegenwoordigde financiële belang samenhangen met hoe snel en effectief een belangenbehartiger gebruikmaakt van sociale media en andere informatiekanalen - en dit dus mede afhankelijk is van hoe diep de zakken zijn van een belangenbehartiger en hoe tech-savvy zij is. Dit zegt nog niets over de juridische kwaliteit, kennis en kunde die nodig zijn voor het voeren van een collectieve procedure of voor het coördineren van de schadeafwikkeling. Ervaring met het voeren van een collectieve procedure of het feit dat een belangenbehartiger op het moment van indienen van de actie

26. In vergelijkbare zin: I. Tillema, 'Exclusieve en concurrerende belangenbehartigers: balanceren op glad ijs?', $A A 2018$, afl. 6, p. 478 .

27. Daarmee bedoelen we de dieselzaken onder de WAMCA tegen Volkswagen c.s., FCA c.s. en Daimler c.s. Zie de respectievelijke rolbeslissingen van de rechtbank Amsterdam in de verscheidende collectieve acties in maart en april 2021 (alle te raadplegen via het centraal register voor collectieve vorderingen).

28. Zie ook E. Bauw \& S. Voet, 'Van stok achter de deur tot keurslijf, NJB 2017 , p. 246. 
betrokken is bij andere procedures zegt op zichzelf ook nog niets over of deze partij het best in staat is om de collectieve procedure in kwestie te coördineren als EB.

In de zoektocht naar zo veel mogelijk gedupeerden en het grootste financiële belang ligt het voor de hand dat belangenbehartigers waar mogelijk over de landsgrenzen kijken. Daarbij kan de belangenbehartiger wel weer op andere grenzen stuiten, in het bijzonder die van het internationaal privaatrecht. Indien de zaak Nederlandse gedupeerden en een Nederlandse gedaagde betreft, zal doorgaans de Nederlandse rechter bevoegd zijn en de rechtsverhouding door Nederlands recht worden beheerst. Bij een buitenlandse achterban is het niet ondenkbaar dat de Nederlandse rechter geen rechtsmacht heeft, of dat vreemd recht van toepassing is op de rechtsverhouding met buitenlandse gedupeerden of gedaagden. De toepasselijkheid van een veelheid aan buitenlandse rechtssystemen in dezelfde collectieve procedure staat op gespannen voet met de door de WAMCA beoogde verhoging van de efficiëntie van de collectieve afwikkeling van massazaken zoals tot uitdrukking komt in art. 1018c lid 5 sub b Rv. Daarnaast zal in deze gevallen het ontvankelijkheidsvereiste van een voldoende nauwe band met de Nederlandse rechtssfeer een obstakel kunnen vormen voor behandeling van de collectieve procedure (art. 3:305a lid 3 sub b BW).

Bij de beoordeling van de geschiktheid van de belangenbehartiger als EB zal de rechter mogelijk zelf - voorgelicht door partijen - ook over de grenzen heen moeten kijken. De introductie van de WAMCA maakt van Nederland een aantrekkelijk forum voor collectieve schadeafwikkeling voor buitenlandse partijen. Achter belangenbehartigers die in Nederland een collectieve vordering instellen, kunnen buitenlandse partijen schuilgaan. Denk aan procesfinanciers of advocatenkantoren die in andere landen ervaring hebben opgedaan met collectieve acties in het algemeen of specifiek met de problematiek waarop ook de Nederlandse collectieve actie ziet. Niet ondenkbaar is dat de wijze waarop buitenlandse partijen zich in dergelijke buitenlandse procedures hebben gedragen, invloed heeft op de beoordeling van de geschiktheid van hun 'vehikel' om als EB een Nederlandse collectieve procedure te coördineren.

De rechtbank is overigens niet gebonden aan de voorkeuren van de belangenbehartigers, maar wijst de in haar ogen meest geschikte partij aan als EB. ${ }^{29}$ Dat is te verklaren vanuit het systeem van de WAMCA: de rechter beoordeelt in het licht van alle omstandigheden van het geval welke partij het meest geschikt is om de coördinerende rol van de $E B$ te vervullen. Dat betekent bijvoorbeeld dat een partij die zich minder heeft geroerd op sociale media, toch EB kan worden. De rechter kan ook een belangenbehartiger die daarom niet verzoekt, aanwijzen als EB. ${ }^{30}$

29. Kamerstukken II 2016/17, 34608, nr. 3, p. 40 en 43 (MvT)

30. Kamerstukken II 2016/17, 34608, nr. 3, p. 43 (MvT).
Tegen de uitspraak waarin de EB wordt aangewezen, staat geen rechtsmiddel open (art. 1018e lid $1 \mathrm{Rv}$, laatste zin). ${ }^{31}$ Dit uit vrees voor vertraging: de uitspraak zou vermoedelijk worden aangevochten door zowel niet-aangewezen belangenbehartigers als aangesproken partijen. ${ }^{32} \mathrm{Wij}$ vragen ons af of de wetgever de belangen van de niet-aangewezen belangenbehartiger niet te gemakkelijk heeft geofferd ten gunste van snelheids- en efficiëntiewinst, ${ }^{33}$ maar het is een gepasseerd station. ${ }^{34}$

\subsection{Sub-en co-EB}

De rechter kan meerdere eiseressen aanwijzen als EB (art. 1018e lid $4 \mathrm{Rv}$ ), bijvoorbeeld als belangenbehartigers met gelijksoortige belangen optreden voor verschillende groepen of als een bepaalde behartiger opkomt voor een specifiek deelbelang. ${ }^{35}$ De wetgever noemt de mogelijkheid om co- en sub-EB's te benoemen. ${ }^{36}$ Het aanwijzen van co-EB's kan voor de hand liggen als bepaalde belangenbehartigers opkomen voor specifieke deelbelangen of als geen van de belangenbehartigers duidelijke belangstelling heeft voor het worden van EB. ${ }^{37}$ De co-EB's zijn dan gezamenlijk hoofdeiser. ${ }^{38}$ Een sub$\mathrm{EB}$ is denkbaar als het gaat om een belangenbehartiger met een specifieke achterban, wiens belangen niet op alle fronten parallel lopen met die van de rest van de gedupeerden, of een belangenbehartiger die voor een specifiek deelterrein zou willen optreden. ${ }^{39}$

De vraag is of de figuur van de sub-EB ook zou kunnen worden gebruikt in gevallen waarin een concurrerende belangenbehartiger een gedaagde in de collectieve procedure beoogt te betrekken die door de 'eerste' belangenbehartiger niet is aangesproken. De vraag die daaraan voorafgaat, is of de concurrerende belangenbehartiger überhaupt gedaagden mag toevoegen aan de procedure (of daaruit mag weglaten). Indien zij een gedaagde mag toevoegen, wat gebeurt er dan met de vordering tegen die gedaagde indien de concurrent niet de EB wordt? Moet die vordering dan worden bepleit door de EB die zelf geen vordering tegen die gedaagde pretendeert? Of kan de rechter de concurrerende belangenbehartiger als sub- of co-EB verantwoordelijk maken voor het voeren van de collectieve procedure tegen de aanvullend aangesproken partij? Staat het de rechtbank vrij om reeds bij het vaststellen van wat de

31. Deze uitspraak wordt overigens ook ingeschreven in het centraal register: art. $1018 \mathrm{e}$ lid $5 \mathrm{Rv}$.

32. Kamerstukken II $2017 / 18,34608$, nr. 6, p. 15 en 20 (NV).

33. Zie daarover ook Bauw \& Voet 2017, p. 246.

34. In de beschikbare literatuur gaat men ervan uit dat dit rechtsmiddelenverbod niet kan worden doorbroken op basis van een van de erkende doorbrekingsgronden. Zie daarover Knigge e.a., in: Sdu Commentaar Burgerlijk procesrecht 2021, art. 1018e Rv, onder 1.4; E. Bauw, J. Biezenaar \& J. van Mourik, Commentaar \& Context. Wetgeving collectieve actie, Den Haag: Boom juridisch 2020, p. 204, voetnoot 80.

35. Kamerstukken II 2017/18, 34608, nr. 9, p. 4 en 5 (NNV).

36. Kamerstukken II 2016/17, 34608, nr. 3, p. 37 en 46 (MvT).

37. Kamerstukken II 2016/17, 34608, nr. 3, p. 43 (MvT); Kamerstukken II 2017/18, 34608, nr. 6, p. 14 (NV).

38. Kamerstukken II 2017/18, 34608, nr. 6, p. 14 (NV).

39. Kamerstukken II 2016/17, 34608, nr. 3, p. 37 (MvT); Knigge e.a., in: Sdu Commentaar Burgerlijk procesrecht 2021, art. 1018e Rv, onder 6. 
collectieve vordering precies inhoudt, te bepalen of deze zich mede richt tegen de toegevoegde gedaagde? Deze vragen spelen momenteel in de dieselzaak tegen Daimler c.s. Aangezien wij enkele gedaagden in die procedure bijstaan als advocaat, zullen wij ons hier niet uitlaten over de antwoorden op deze vragen.

\subsection{Niet-concurrerende belangenbehartigers en individuen als mede-eisers}

Onder het pre-WAMCA-regime was het niet ongebruikelijk dat collectieve vorderingen werden ingesteld door meerdere stichtingen en/of verenigingen gezamenlijk. Dit past niet binnen het model van de WAMCA, die ervan uitgaat dat de EB één partij is. Uitgangspunt van het wetsvoorstel was dat elke representatieve belangenorganisatie bereid moet zijn om EB te worden. ${ }^{40}$

De rechtbank zal de ontvankelijkheid van elk van de eiseressen moeten toetsen. Wat ons betreft kan de rechtbank meegaan in de suggestie van gezamenlijke eiseressen wie van hen als EB moet worden aangewezen. De rechtbank kan verschillende belangenbehartigers aanwijzen als co- of sub-EB voor de behartiging van onderscheiden belangen.

Indien twee samenwerkende stichtingen of verenigingen optreden als mede-eiseressen, vertegenwoordigd door dezelfde advocaat, en indien zij het erover eens zijn dat eiseres 1 als EB moet worden aangewezen, zou men zich kunnen afvragen hoe zinvol het is om de ontvankelijkheid van eiseres 2 te toetsen. Aan het verloop van de procedure zal dat in beginsel niets wijzigen. Dat is echter een 'in beginsel': de situatie kan veranderen als onenigheid ontstaat tussen de twee belangenbehartigers. In dat geval zal de niet-aangewezen eiseres wellicht een eigen advocaat aanstellen, eigen proceshandelingen willen verrichten of de rechtbank willen verzoeken om de andere eiseres te mogen vervangen als EB. Dat zal zij alleen mogen doen indien zij voldoet aan de eisen van art. 3:305a BW. Als eisers uit elkaar vallen in gewone, niet-collectieve procedures, kunnen zij worden bijgestaan door afzonderlijke advocaten en hun eigen proceshandelingen verrichten. In uitzonderlijke gevallen zou de procedure kunnen worden gesplitst, waarbij de oorspronkelijke dagvaarding blijft gelden als procesinleiding van beide procedures. ${ }^{41}$

Niet in elke situatie zou echter plaats moeten zijn voor een belangenbehartiger die niet bereid is om de rol van EB op zich te nemen. Een in principe concurrerende belangenbehartiger kan bijvoorbeeld besluiten zich na het uitbrengen van een eigen dagvaarding aan te sluiten bij een andere belangenbehartiger, bijvoorbeeld om een derde belangenbehartiger buitenspel te zetten. Door de krachten te bundelen zouden deze samenwerkende partijen de belangen van een grotere achterban met een groter financieel belang behartigen dan de con-

40. Kamerstukken II 2017/18, 34608, nr. 9, p. 4 (NNV).

41. Vgl. Snijders, in: GS Burgerlijke Rechtsvordering, art. 222 Rv, aant. 3, voetnoot 1 . current. De belangenbehartiger in kwestie kan dan verder 'achteroverleunen': de belangen van haar achterban worden behartigd door de EB en zij sluit zich aan bij de standpunten van de EB. Mogelijk zal dan een situatie ontstaan waarin de belangenbehartiger nauwelijks aanvullende kosten hoeft te maken, maar wel een eigen vergoeding zal opeisen in onderhandelingen over een schikking. ${ }^{42}$ Dat is niet een rechtens te respecteren belang. In de woorden van de minister:

'Ik vind dat er in een collectieve schadevergoedingsprocedure geen plaats kan zijn voor belangenorganisaties die hoofdzakelijk vanuit winstoogmerk opereren en die vervolgens niets doen. 43

Dit zou kunnen betekenen dat een dergelijke belangenbehartiger alsnog niet-ontvankelijk moet worden verklaard wegens het ontbreken van voldoende belang (art. 3:303 BW). Indien de belangenbehartiger tegen dit deelvonnis hoger beroep instelt, doemt wel weer vertraging op. ${ }^{44}$

Onder het pre-WAMCA-regime waren soms ook individuen mede-eisers, hetzij met eigen vorderingen die op hun individuele positie zagen, ${ }^{45}$ hetzij slechts ter ondersteuning van de collectieve vordering. ${ }^{46}$ Individuele mede-eisers zouden onder het oude en het nieuwe regime niet-ontvankelijk moeten zijn in een collectieve vordering omdat zij geen stichting of vereniging zijn en geen voldoende concreet eigen belang hebben, ${ }^{47}$ maar op dit punt wordt niet altijd verweer gevoerd. Overigens kan de bewezen medestand van deze individuen mogelijk een rol spelen in de ontvankelijkheidstoets van representativiteit (art. 3:305a lid $2 \mathrm{BW}$ ) en de besproken selectiecriteria van de grootte van de achterban en het vertegenwoordigde financiële belang (art. 1018e lid 1 sub a en b Rv). Vergelijk de ruim 7.000 mede-eisers in de zaak Clara Wichmann c.s./Staat over gratis anticonceptie. ${ }^{48}$ In individuele vorderingen kunnen de individuele mede-eisers wel ontvankelijk zijn, maar dan is er slechts sprake van een gevoegde behandeling van een collectieve vordering en een individuele vordering.

42. Of, en zo ja, in hoeverre een niet-aangewezen belangenbehartiger aanspraak kan maken op vergoeding die de daarbij aangesloten gedupeerden ontvangen, zal (mede) afhangen van de contractuele afspraken tussen partijen.

43. Kamerstukken II 2017/18, 34608, nr. 9, p. 4 (NNV).

44. Zie par. 3.1 hiervoor over de concurrerende belangenbehartiger die hoger beroep instelt wegens niet-ontvankelijkverklaring om andere redenen. Wij gaan ervan uit dat de niet-ontvankelijkverklaring van een van de partijen jegens die partij een eindvonnis is, ook als de vorderingen worden behandeld 'als een zaak' (art. 1018d lid 3 Rv). Dergelijke complicaties kunnen voor een rechtbank aanleiding zijn om de belangenbehartiger eenvoudigweg niet aan te wijzen als EB. Daartegen staat geen hoger beroep open (art. 1018e lid 1 Rv, laatste zin).

45. Bijv. Rb. Oost-Brabant 28 mei 2005, ECLI:NL:RBOBR:2015:3873 (FNV c.s./Nederlandse Radiateuren Fabriek).

46. Bijv. Hof s-Gravenhage 9 februari 2010, ECLI:NL:GHSGR: 2010:BL3061 (Clara Wichmann c.s./Staat, borstkankeronderzoek).

47. Zoals gebeurde in Rb. Den Haag 26 mei 2021, ECLI:NL:RBDHA: 2021:5337 (Milieudefensie c.s./Shell), r.o. 4.2.7.

48. Dagvaarding van 17 februari 2020, gepubliceerd in centraal register voor collectieve vorderingen. 


\section{5 (Dis)functioneren van de EB}

\subsection{De rolverdeling tussen EB en overige belangenbehartigers}

Als dan eenmaal een EB is aangewezen, verricht die mede als vertegenwoordiger van de niet-aangewezen belangenbehartigers in beginsel de proceshandelingen (art. 1018e lid $3 \mathrm{Rv}$ ). De niet-aangewezen belangenbehartigers blijven partij in de collectieve procedure (eveneens art. 1018e lid $3 \mathrm{Rv}$ ). De wetgever heeft de EB verantwoordelijk gemaakt voor de coördinatie van de collectieve procedure en naar voren geschoven als aanspreekpunt voor de gedaagde, ook bij schikkingsonderhandelingen. ${ }^{49}$ Duidelijkheid over de onderhandelingspartner - en diens achterban - die kan beslissen over een schikkingsvoorstel moet de schikkingsbereidheid van de aangesproken partij bevorderen..$^{50}$

Niet-aangewezen belangenbehartigers moeten een EB monitoren, waar nodig bijsturen, en input leveren om de belangen van alle gedupeerden zo goed mogelijk in beeld te brengen bij de EB. ${ }^{51}$ Zo zouden zij moeten kunnen voorkomen dat de EB kiest voor een niet-kansrijke processtrategie of voor een te laag bedrag schikt. Daarnaast stelt het minder ervaren belangenbehartigers in staat om ervaring op te doen in het voeren van een collectieve procedure, zo heeft Tillema naar voren gebracht. ${ }^{52}$ Dit moet de concurrentie tussen en de kwaliteit van belangenbehartigers vergroten. De rechter kan niet-aangewezen belangenbehartigers ook in staat stellen om proceshandelingen te verrichten.

Dat laatste ligt overigens weinig voor de hand als verschillende eiseressen gezamenlijk één dagvaarding hebben uitgebracht, al liet de rechtbank Amsterdam in de vagina.nl-zaak beide belangenbehartigers toe proceshandelingen te verrichten. De rechtbank wees Stichting Stop Online Shaming aan als EB en mede-eiseres Stichting Expertisebureau Online Kindermisbruik mocht proceshandelingen verrichten, met dien verstande dat deze beperkt dienden te blijven tot de belangen van kinderen, overeenkomstig haar statutaire doel. ${ }^{53}$

Rechters zouden geneigd kunnen zijn om niet-aangewezen belangenbehartigers ruimhartig de kans te geven eigen processtukken in te dienen, gelet op het fundamentele karakter van de rechten van deze mede-eiseressen op hoor en wederhoor en

49. Kamerstukken II 2016/17, 34608, nr. 3, p. 42 (MvT); Kamerstukken II 2017/18, 34608, nr. 6, p. 3 en 30 (NV).

50. Kamerstukken II 2016/17, 34608, nr. 3, p. 42 (MvT). Zie ook Kamerstukken II 2017/18, 34608, nr. 9, p. 7 (NNV). De rol van de EB bij een schikking blijkt ook uit de bevoegdheid van de rechter om zowel de EB als de aangesproken partij te bevelen om een voorstel te doen voor een collectieve schadeafwikkeling (art. 1018i Rv).

51. Kamerstukken II 2016/17, 34608, nr. 3, p. 45 (MvT); Kamerstukken II 2017/18, 34608, nr. 6, p. 3 en 30 (NV).

52. I. Tillema, 'Exclusieve en concurrerende belangenbehartigers: balanceren op glad ijs?', $A A$ 2018, afl. 6, p. 480.

53. Rb. Amsterdam 28 oktober 2020, zaak-/rolnr. C/13/680916 / HA ZA 20-284, r.o. 5.30. Gepubliceerd in centraal register, maar niet op rechtspraak.nl; referentie aan deze beslissing is te vinden in het daaropvolgende tussenvonnis, Rb. Amsterdam 18 november 2020, ECLI:NL:RBAMS:2020:5826, r.o. 1.1. een eerlijke procesgang (art. 6 EVRM), de afwezigheid van een rechtsmiddel tegen aanwijzing van de EB en de ruimte die de wetsgeschiedenis biedt. Aan de andere kant: het toelaten van aanvullende processtukken leidt ertoe dat de rechter in een bepaalde fase van de procedure feitelijk afstapt van het systeem van de EB. Dat doet afbreuk aan de efficiëntiewinst die is beoogd met het coördinerende systeem van de EB. Dit wijst in de richting van een terughoudende toepassing van het instrument, zeker bij afwezigheid van een gegrond verschil van mening tussen de EB en de niet-aangewezen belangenbehartiger.

Als een niet-aangewezen belangenbehartiger voor nieuwe juridische of feitelijke ankers gaat liggen, kan de vraag rijzen of het processtuk kwalificeert als (verkapte) eiswijziging. Dergelijke stellingnames in aanvullende processtukken zullen - naar wij vermoeden - op gespannen voet staan met het uitgangspunt dat de rechter bij benoeming van de EB eveneens de inhoud van de collectieve vordering vaststelt (art. 1018e lid 2 Rv). Gezien die vaststelling - waarop de achterban zijn beslissing baseert om al dan niet uit te opteren - menen wij dat de rechter hoe dan ook terughoudender moet omgaan met het toestaan van eiswijzigingen dan in een reguliere procedure.

\subsection{Conflictsituaties}

Er zullen zich situaties gaan voordoen waarin de EB en de niet-aangewezen belangenbehartiger het oneens zijn over de processtrategie. De EB kan volgens de niet-aangewezen belangenbehartiger bijvoorbeeld voor ankers gaan liggen die juridisch geen kans van slagen hebben, of juridische mogelijkheden laten liggen. Denkbaar is ook dat een EB kiest voor een zo goed als zekere schikking voor een relatief laag bedrag, terwijl een niet-aangewezen belangenbehartiger wil doorprocederen voor een hoger schadevergoedingsbedrag. ${ }^{54}$ Verder is mogelijk dat de EB kiest voor een strategie die negatief kan uitpakken voor de deelbelangen van een niet-aangewezen belangenbehartiger of voor de strategie van een sub-EB. Denk bijvoorbeeld aan de situatie dat de rechter een belangenbehartiger als sub-EB verantwoordelijk maakt voor het voeren van de collectieve procedure ten behoeve van een specifieke groep buitenlandse gedupeerden. De EB kan het standpunt innemen dat voor het toepasselijke recht een bepaald aanknopingspunt geldt als gevolg waarvan op de vorderingen van de buitenlanders een rechtsstelsel van toepassing is waaronder hun vorderingen zouden zijn verjaard. Kortom: genoeg potentie voor conflictsituaties.

De vraag is hoe de collectieve procedure uit dergelijke conflictsituaties kan komen. Volgens de minister kan de niet-aangewezen belangenbehartiger zo nodig bij de rechter 'aan de bel trekken' als zij van mening is dat de EB onvoldoende oog heeft voor bepaalde vertegenwoordigde belangen. ${ }^{55}$ De wetgever

54. C.M.D.S. Pavillon \& D.G.J. Althoff, 'Wijze raad is halve daad of veel raad maar weinig baat', $M v V 2017$, afl. 3, p. 109.

55. Kamerstukken II $2017 / 18,34608$, nr. 6, p. 15 (NV); Kamerstukken II 2017/18, 34608, nr. 9, p. 4 (NNV). 
noemt in ieder geval twee instrumenten die de rechter zou kunnen inzetten in geval van conflictsituaties. Zo kan hij nietaangewezen belangenbehartigers toestaan om aanvullende processtukken in te dienen. ${ }^{56}$ Het tweede instrument is vervanging van de EB. ${ }^{57}$ Daarbij lijkt het te gaan om een instrument voor het 'uiterste geval', dat vooral is bedoeld voor situaties dat een EB niet langer voldoet aan de ontvankelijkheidseisen of niet meer voldoende solvabel is. ${ }^{58}$ De vraag is dan ook welke rol dit instrument in de praktijk zal kunnen spelen bij conflictsituaties. De flexibiliteit die de rechtbank heeft, stelt haar overigens ook in staat om te experimenteren met andere oplossingen. ${ }^{59}$ Tillema suggereert de instelling van een steering committee, waarbij de betrokken belangenbehartigers worden verenigd onder voorzitterschap van de EB. ${ }^{60}$

Welke toets hanteert de rechter bij het ingrijpen in een conflictsituatie? Het ligt voor de hand dat een minder strenge toets geldt voor het toestaan om aanvullende processtukken in te dienen dan voor vervanging van de EB - zeker omdat de rechter de niet-aangewezen belangenbehartiger ook zonder conflictsituatie kan toestaan om eigen processtukken in te dienen.

De wetsgeschiedenis laat het aan de rechter om regie te voeren over de indiening van eigen processtukken door andere belangenbehartigers. De rechtbank kan de andere belangenbehartiger(s) bijvoorbeeld uitsluitend toestaan een aanvullend stuk in te dienen ten aanzien van een bepaald gezichtspunt dat ten onrechte niet naar voren is gebracht door de $\mathrm{EB}-\mathrm{al}$ dan niet nadat de EB haar eigen stuk heeft ingediend. ${ }^{61}$ Mogelijk zal de rechtbank de EB bevelen haar concept ruim voor de roldatum aan de andere belangenbehartiger(s) ter beschikking te stellen, maar dit zal lastig te handhaven zijn.

Stel dat een niet-aangewezen belangenbehartiger bij de rechter aan de bel trekt omdat de EB haar structureel buiten de procedure zou houden. $\mathrm{Zij}$ zal de overige procespartijen daarvan op de hoogte moeten brengen - haar advocaat mag zich in ieder geval niet tot de rechter wenden zonder de advocaten van de andere partijen in te kopiëren. ${ }^{62}$ Dat vereist zorgvuldig formuleren, want de belangenbehartigers zullen de gedaagde(n) niet al te veel inzicht willen bieden in hun strategische afwegingen. Ook hier rijzen vragen, zoals: mogen alleen de andere belangenbehartigers zich uitlaten over het verzoek of ook de gedaagde? Wij menen dat laatste, hoewel wij ons kunnen voorstellen dat de rechter meer gewicht zal toekennen aan de visie van de andere belangenbehartiger(s).

56. Kamerstukken II 2017/18, 34608, nr. 6, p. 21 en 30 (NV).

57. Kamerstukken II 2016/17, 34608, nr. 3, p. 45 (MvT); Kamerstukken II 2017/18, 34608, nr. 6, p. 30 (NV).

58. Zie Kamerstukken II 2016/17, 34608, nr. 3, p. 45 (MvT); Kamerstukken II 2017/18, 34608, nr. 6, p. 21 (NV).

59. Kamerstukken II 2017/18, 34608, nr. 6, p. 21 (NV).

60. Zie voor deze aan de VS ontleende suggestie I. Tillema, 'Schikken in onzekerheid', TvPP 2020, afl. 5, p. 168-169.

61. Kamerstukken II 2016/17, 34608, nr. 3, p. 46 (MvT).

62. Regel 21 Gedragsregels advocatuur.
De EB werkt doorgaans samen met een procesfinancier. Het kan voorkomen dat er - om wat voor reden dan ook - heibel ontstaat tussen de EB en haar financier. Dit kan vervolgens de voortgang van de collectieve procedure in gevaar brengen. Stel dat een andere belangenbehartiger daar lucht van krijgt. Naar onze mening zou de rechter op haar verzoek op grond van art. $22 \mathrm{Rv}$ inlichtingen kunnen verlangen van de EB. ${ }^{63} \mathrm{Als}$ de procesfinancier om wat voor reden dan ook de geldkraan dichtdraait, zal de EB mogelijk keuzes moeten maken die ten koste gaan van de belangen van de gehele achterban. In dergelijke gevallen ligt het instrument van vervanging van de EB wat ons betreft eerder voor de hand.

Een vraag die in het verlengde van deze bespiegelingen ligt, is hoe het zit met de belangen van de achterban van een disfunctionerende EB. Heeft de rechtbank een rol in het op de hoogte brengen van de achterban over het disfunctioneren? Wanneer de rechtbank slechts beslist dat een andere belangenbehartiger ook processtukken mag nemen, lijkt ons dat niet nodig, maar bij vervanging van de EB kan dat anders zijn. Het lijkt ons in ieder geval logischer dat de rechtbank de informatieverschaffing zelf verzorgt dan dat zij dat overlaat aan de nieuwe EB. Het zou wel erg ver gaan als de oude EB de contactgegevens van 'haar' deelnemers moet verschaffen aan de nieuwe EB. Indien de rechtbank de achterban wil informeren, zal zij vermoedelijk een bevel tot medewerking moeten doen aan de oude EB om een bericht op de website te plaatsen en deelnemers te informeren. Indien de EB insolvabel wordt en om die reden wordt vervangen, ligt het meer voor de hand dat de informatievoorziening wordt overgelaten aan de curator of bewindvoerder.

Het is daarnaast niet ondenkbaar dat een achterban om vergelijkbare redenen als niet-aangewezen belangenbehartigers ontevreden rakt over de verrichtingen van een EB. Leden van de achterban zullen gebruik moeten maken van de middelen die hun ter beschikking staan om de koers van de EB bij te sturen, bijvoorbeeld via de mechanismen bedoeld in art. 3:305a lid 2 sub b BW of door hun aansluiting te beëindigen (art. 3:305a lid 2 sub d onder $9^{\circ} \mathrm{BW}$ ). Wij zien niet direct ruimte voor een rechtstreeks verzoek van een vertegenwoordiging van de achterban aan de behandelend rechter, maar het lijkt ook niet uitgesloten. Een dergelijke vertegenwoordiging zou ook een niet-aangewezen belangenbehartiger kunnen benaderen.

Ook bij schikkingsonderhandelingen kan een niet-aangewezen belangenbehartiger ontevreden zijn over het optreden van de EB. De minister gaat ervan uit dat de EB voor de gehele achterban kan beslissen of een schikking wordt gesloten. ${ }^{64}$ Dat zou betekenen dat voor de totstandkoming van een schikking

63. Deze inlichtingen zullen niet noodzakelijkerwijs ook aan de gedaagde moeten worden verschaft; zie art. 22 lid 2 Rv. De minister refereert hieraan (en aan HR 20 december 2002, ECLI:NL:HR:2002:AE3350 (Lightning Casino)) in het kader van het beoordelen van de financieringsovereenkomst tussen belangenbehartiger en financier. Zie Kamerstukken II 2014/15, 34059, nr. 7 (NvW).

64. Kamerstukken II 2017/18, 34608, nr. 9, p. 7 (NNV). 
geen handtekening is vereist van de niet-aangewezen belangenbehartigers. In de praktijk zal een schikking echter wel problematisch worden indien zij daarmee niet instemmen. Zij zullen dan bezwaren uiten tegenover de rechtbank die de schikking moet goedkeuren (art. 1018h Rv), en het is vaak lastig te voorspellen hoe de rechtbank daarmee om zal gaan. Wordt de schikking goedgekeurd, dan bestaat de kans dat de niet-aangewezen belangenbehartigers hun achterban aansporen om gebruik te maken van de mogelijkheid tot opt-out. Dit kan de finaliteit van de schikking in gevaar brengen. Mogelijk dat dit er in de praktijk toe leidt dat ook niet-aangewezen belangenbehartigers plaatsnemen aan de onderhandelingstafel.

\section{Slot}

De WAMCA is mede ontworpen om gelijksoortige vorderingen van verschillende collectieve belangenbehartigers te trechteren tot één procedure. In de praktijk kunnen zich conflictsituaties en andere complicaties voordoen waarvoor de wet en wetsgeschiedenis geen oplossing bieden. Daarnaast rijzen interessante vragen wanneer de partijen afwijken van die regels. In dit artikel verkennen wij een aantal van dergelijke scenario's en knelpunten die op de loer liggen. Op de vragen die wij stellen, zijn ongetwijfeld andere antwoorden mogelijk dan de voorstellen die wij in dit artikel doen, en de WAMCA roept ook bij allerlei andere onderwerpen procesrechtelijke vragen op. Nieuwe verwikkelingen in het vooruitzicht dus - het wordt smullen voor de liefhebbers van burgerlijke rechtsvordering de komende jaren. 